\title{
How big should the knowledge be for small nerve ultrasound?
}

\author{
Wie groß sollte das Fachwissen beim Ultraschall kleiner Nerven sein?
}

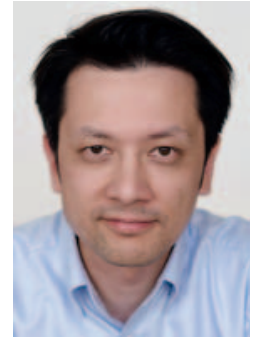

Stefan Meng
Correspondence

Stefan Meng

Center for Anatomy and Cell Biology, Medical University

of Vienna Radiology, KFJ Hospital, Vienna

stefan.meng@meduniwien.ac.at

Bibliography

DOI https://doi.org/10.1055/a-0900-4855

Published online: 2019

Ultraschall in Med 2019; 40: 403

(c) Georg Thieme Verlag KG, Stuttgart · New York

ISSN 0172-4614
At an astonishingly fast pace technical advances are pushing the limits of diagnostic ultrasound. Machines with increasingly higher resolution show us tiny structures we have never thought we could see or even scan for pathologies. Very sensitive color doppler methods show us intraneural vascularization patterns. Strong postprocessing algorithms allow us to modify the image and thus potentially enhance our perception. Although some technical advances fall short of great initial expectations ultrasound images have improved a lot.

But what about us? At the same pace as technical innovations push the boundaries of visibility the very same innovations push us. If image resolution allows the assessment of small nerves, do we know all small nerves? If we can assess single fascicles is it enough to look at the nerve as a whole? Is it ok to measure the cross sectional area only? In countless publications and conferences everybody keeps reminding us that ultrasound strongly depends on the examiner. In a fierce dispute spanning several issues of Ultraschall in der Medizin/European Journal of Ultrasound we are struggling to find a consensus regarding the access of non-physicians to diagnostic ultrasound.

Ultrasound is partly similar to a craftmanship based on skills and experience, but as the number of structures accessible to this method rises ultrasound must also be performed with profound knowledge on anatomy and pathology. As in all areas of medicine specialization is the consequence. Thus, ultrasound training has to adapt. We have to adapt.

\section{Wie groß sollte das Fachwissen beim Ultraschall kleiner Nerven sein?}

Mit überraschend hohem Tempo sprengt der technische Fortschritt die Grenzen des diagnostischen Ultraschalls. Geräte mit zunehmend besserer Auflösung zeigen uns winzige Strukturen, von denen wir nie gedacht haben, dass wir sie sehen, geschweige denn sogar Pathologien untersuchen können. Sehr sensitive Farbdoppler-Methoden zeigen uns intraneurale Vaskularisationsmuster. Leistungsfähige Post-Processing-Algorithmen ermöglichen es uns, das Bild zu modifizieren und somit möglicherweise unsere Perzeption zu verbessern. Obwohl einige technische Fortschritte hinter den ursprünglichen großen Erwartungen zurückbleiben, haben sich die Ultraschallbilder erheblich verbessert.

Gilt das auch für uns? Im gleichen Tempo, in welchem technische Innovationen die Grenzen der Visibilität verschieben, fordern uns diese Innovationen heraus. Wenn die Bildauflösung die Beurteilung kleiner Nerven ermöglicht, kennen wir alle kleinen Nerven? Wenn wir einzelne Faszikel beurteilen können, reicht es dann aus, den Nerv als Ganzes zu betrachten? Darf nur die Querschnittsfläche gemessen werden? In unzähligen Publikationen und Konferenzen werden wir immer wieder daran erinnert, dass Ultraschall stark vom Untersucher abhängt. In einem heftigen Disput, der sich über mehrere Ausgaben von Ultraschall in der Medizin/European Journal of Ultrasound erstreckt, ringen wir darum, einen Konsens zu finden, inwieweit auch Nichtmediziner den diagnostischen Ultraschall durchführen können.

Ultraschall ähnelt teilweise einem Handwerk, welches auf Können und Erfahrung beruht. Da jedoch die Anzahl der Strukturen, die mit dieser Methode unsuchbar sind, ansteigt, sind bei der Durchführung der Sonografie profunde Kenntnisse in Anatomie und Pathologie dringend erforderlich. Wie in allen Bereichen der Medizin folgt daraus eine Spezialisierung. Dementsprechend muss sich das Ultraschalltraining dem anpassen - und wir müssen uns anpassen. 